\title{
The Relationship of the Major Murine Histocompatibility Region Associated IA Antigens to Mitogen Responses '
}

\author{
JOHN E. NIEDERHUBER, M.D., ${ }^{23}$ JEFFREY A. FRELINGER, Ph.D., \\ ELIZABETH DUGAN, Ph.D., ${ }^{4}$ AND DONALD C. SHREFFLER, Ph.D. ${ }^{3}$ \\ Departments of Surgery, Microbiology, and Human Genetics, The University of Michigan \\ Medical Center, Ann Arbor, Michigan 48104
}

Submitted for publication January 3,1976

The mouse and other mammals have a large number of histocompatibility $(\mathrm{H})$ gene loci (perhaps several hundred) controlling cell-membrane alloantigens. Only one locus, however, is a strong $\mathrm{H}$ locus and is termed the major histocompatibility complex (MHC). A difference between donor and recipient at the MHC will prevent the growth of nearly all tumor allotransplants and result in rapid rejection of skin allografts. The murine MHC, $(H-2)$, is located in the $I X$ th linkage group of the 17 th chromosome and is composed of five regions denoted as $K, I, S$, $G, D[1]$. The $H-2$ gene complex has served as a model for MHC of other mammals and the similarity of $H-2$ and the $H L-A$ gene complex of man is striking.

In addition to the classical $\mathrm{H}-2$ histocompatibility antigens of the $K$ and $D$ regions, the $I$ region, originally defined by immune response $(I r-1)$ genes [2], contains genes coding for a system of lymphocyte alloantigens. These antigens have been designated Ia ( $I$ region associated) [3] and to date $21 \mathrm{spec}-$ ificities have been identified (for review, Ref. [4]). The Ia antigens have a restricted distribution with expression on the majority of $B$ lymphocytes and a subpopulation of $T$ lymphocytes [5-11].

\footnotetext{
'Supported by Damon Runyon DRG-1260, Michigan Kidney Foundation, and NIH Grants RO1-AI-11962-01 and RO1-AI-12153-01.

${ }^{2}$ Present address: Department of Microbiology, The University of Michigan Medical Center, Ann Arbor, Mich. 48104.

${ }^{3}$ Recipient of U.S. Public Health Service Research Career Development Award.

${ }^{4}$ Fellow of the Jane Coffin Childs Memorial Fund for Mcdical Research.
}

The purpose of this study was to determine if specific mitogen reactive cells expressed the Ia surface molecules and if there was any association between the Ia determinant and specific mitogen receptors.

\section{MATERIALS AND METHODS}

Mice. B10.BR $\left(H-2^{k}\right)$ mice were purchased from Jackson Laboratory, Bar Harbor, Maine. All other strains used in experiments or for antisera production were maintained in Dr. Niederhuber's or Dr. Shreffler's colony at The University of Michigan. In each experiment, mice were matched for age and sex.

Antisera. Antisera specific for Ia antigens were prepared by reciprocal immunizations of A.TH $\left(H-2^{12}\right)$ and A.TL $\left(H-2^{t 1}\right)$ mice with lymphoid tissues. A.TH anti-A.TL $\left(\mathrm{Ia}^{k}\right)$ serum and A.TL anti-A.TH $\left(\mathrm{Ia}^{s}\right)$ serum have been extensively characterized by microcytotoxic and absorption studies $[4,10]$. These sera are consistently cytotoxic for $70 \%$ of lymph node cells and $50 \%$ of spleen cells. Previous studies have demonstrated that the majority of B lymphocytes are Ia positive while only a subpopulation of $T$ cells carry the Ia determinants [10]. The IgG fraction of A.TH anti-A.TL serum was prepared by Pevicon block electrophoresis, eluted with $0.1 M$ phosphate buffer, and dialyzed against tissue culture media [12].

Anti-Thy-1.2 serum was prepared in A.AKR $\left(H-2^{a !}, T h y-1^{a}\right)$ mice against A.AL $\left(H-2^{a}, T h y-1^{b}\right)$ thymocytes. Anti-H-2 serum specific for the $H-2 K^{s}$ determinant $(\mathrm{H}-2.19)$ was prepared in $(\mathrm{A} \times \mathrm{A} . \mathrm{AL})_{\mathrm{Fl}}\left(H-2^{a} / H-2^{a}\right)$ mice against A.TL $\left(H-2^{t L}\right)$ cells and anti- 
serum specific for $H-2 K^{k}$ antigens $(\mathrm{H}-2.11$ and $\mathrm{H}-2.23)$ was prepared in A.TL $(\mathrm{H}-2)$ mice by immunizing with A.AL $\left(H-2^{a l}\right)$ cells. All normal sera and antisera are clarified by centrifugation, heat inactivated, and sterilized by passage through a $0.22 \mu \mathrm{m}$ Millipore filter (Millipore Corp., Bedford, Mass.). Sera are stored at $-70^{\circ} \mathrm{C}$ in undiluted aliquots.

Culture conditions. Spleen cells were dispersed by teasing in serum-free RPMI 1640 media (Microbiological Associates, Bethesda, Md.) supplemented with $3 \mathrm{ml}$ of Hepes $(1 M)$ and $50 \mu \mathrm{g} / \mathrm{ml}$ gentamycin/100 $\mathrm{ml}$ media. Quadruplicate cultures of $5 \times 10^{5}$ viable cells were incubated in multi-well Linbro plates (Linbro Chemical Co., New Haven, Conn.). Cultures were stimulated with a dose range of $\mathrm{T}$-cell and B-cell specific mitogens. The B-cell mitogen LPS was derived from Serratia marcesens (Difco Laboratories, Detroit, Mich.) and further purified according to the method of Nowotny et al. [13]. Con-A was purchased from Calbiochem (Elk Grove Village, Ill.), PHA$M$ was obtained from Difco Laboratories, and Leucoagglutinin, a highly purified form of PHA was from the Pharmacia Fine Chemicals, Uppsala, Sweden.

Culture plates of lymphoid cells stimulated with LPS were incubated for $48 \mathrm{hr}$ at $37^{\circ} \mathrm{C}$ in an atmosphere of $5 \% \mathrm{CO}_{2}$. Con-A and PHA stimulated cultures were incubated for $72 \mathrm{hr}$. During the last $12-18 \mathrm{hr}$ of culture, $0.2 \mu \mathrm{Ci}$ of ${ }^{3} \mathrm{H}$-thymidine $(2 \mathrm{Ci} / \mathrm{mM})$ was present in the cultures. Cultures were harvested with a multiple sample harvester (Otto Hiller Co., Madison, Wis.), collected on glass fiber filters and counted in a liquid scintillation counter.

Thymus-dependent lymphocytes were isolated from whole spleen using the nylon-wool (LP-1 leuko-pak leukocyte filter, Fenwal Laboratories, Morton Grove, Ill.) method described by Julius et al. [14]. These cells were $80-90 \%$ sensitive to antiThy-1 serum plus complement and had no significant response to LPS.

B cells were prepared from whole spleen by twice treating the mixed cell population with anti-Thy-1.2 serum and complement. The resistant cell population was $95 \%$ B cells and demonstrated no T-cell functions.

Antiserum treatment of cultured cells. For blocking experiments, spleen cells or purified $\mathrm{T}$ - and B-cell subpopulations were incubated for $30 \mathrm{~min}$ at $37^{\circ} \mathrm{C}$ with anti-Ia serum, control serum, or normal serum without complement. These cells were then washed extensively by multiple centrifugations in media before culturing. In experiments where cells bearing the Ia determinants were actually eliminated from the cultured cell population, the cells were first incubated with antisera in a dilution of $1: 5$ or $1: 10$ at $37^{\circ} \mathrm{C}$ for $20-30 \mathrm{~min}$. The cells were then pelleted by slow centrifugation, the antiserum was decanted, and the cells were resuspended in agarose absorbed rabbit complement, incubated for $30 \mathrm{~min}$ at $37^{\circ} \mathrm{C}$, and then washed by centrifugation in media. Lysed and damaged cells were removed by centrifugation on a gradient of Lymphoprep (density $1.077 \mathrm{~g} / \mathrm{ml}$ ) (Nyegaard and Co. A/S, Oslo, Norway). The cells were then counted in a hemacytometer and adjusted to $5 \times 10^{6}$ viable cells $/ \mathrm{ml}$. Each culture has 5 $\times 10^{5}$ cells and the final volume in each culture well was $0.3 \mathrm{ml}$.

\section{RESULTS}

Anti-1a serum blocking of LPS stimulation. Spleen cells were incubated with appropriate anti-Ia serum without complement for $30 \mathrm{~min}$ at $37^{\circ} \mathrm{C}$. The cells were then washed by centrifugation in media 3-4 times. Equal numbers of viable cells exposed to normal serum, anti-H-2 serum, or anti-Ia serum were cultured with a dose curve of 0.1 to 100 $\mu \mathrm{g} / \mathrm{ml}$ LPS. The results of five experiments show a persistent partial inhibition $(35.6 \% \pm$ 11.8) $(P<0.005)$ of the response to $50 \mu \mathrm{g} / \mathrm{ml}$ of LPS (Table 1). The peak response in control cultures occurred with LPS concentration of $50 \mu \mathrm{g} / \mathrm{ml}$. No significant inhibition was observed with nonappropriate anti- $\mathrm{Ia}^{\mathrm{s}}$ serum $(3.4 \% \pm 13.7)$ or with anti-H- $2 \mathrm{~K}^{s}$. serum in Expts 2 and 3. In Expt 3 (Table 1), 
TABLE 1

Inhibition of the LPS Mitogenic Response by Incubating Lymphocytes with Anti-Ia Serum before Culturing with LPS

\begin{tabular}{|c|c|c|c|c|c|}
\hline Expt & Strain & $\begin{array}{c}\text { I } \\
\text { region }\end{array}$ & $\begin{array}{c}\text { Antiserum } \\
\text { blocking }\end{array}$ & $\mathrm{cpm} \pm \mathrm{SD}^{a}$ & $\begin{array}{c}\% \\
\text { Suppression }\end{array}$ \\
\hline 1 & A.TL & $\mathrm{k}$ & $\begin{array}{l}\text { None } \\
\text { Anti-Ia } \\
\text { Anti-Ia }^{k}\end{array}$ & $\begin{aligned} 10461 & \pm 1944^{b} \\
11830 & \pm 3752 \\
8088 & \pm 914\end{aligned}$ & $\begin{array}{r}- \\
-13 \\
23\end{array}$ \\
\hline 2 & A.TL & k & $\begin{array}{l}\text { None } \\
\text { Anti-Ia } \\
\text { Anti-H-2K }^{s} \\
\text { Anti-Ia }\end{array}$ & $\begin{array}{r}10704 \pm 2198 \\
8110 \pm 1922 \\
9741 \pm 3876 \\
5114 \pm 1190\end{array}$ & $\begin{array}{r}- \\
24 \\
9 \\
52\end{array}$ \\
\hline 3 & A.TL & k & $\begin{array}{l}\text { None } \\
\text { Anti-Ia } \\
\text { Anti-H-2K } \\
\text { Anti-Iak }\end{array}$ & $\begin{array}{l}4870 \pm 900 \\
4959 \pm 1964 \\
4374 \pm 1764 \\
2837 \pm 708\end{array}$ & $\begin{array}{r}-\overline{2} \\
-10 \\
42\end{array}$ \\
\hline 4 & B10.BR & $\mathbf{k}$ & $\begin{array}{l}\text { None } \\
\text { Anti-Ia }^{s} \\
\text { Anti-Ia }^{k}\end{array}$ & $\begin{array}{l}21569 \pm 792 \\
19852 \pm 1314 \\
15902 \pm 854\end{array}$ & $\begin{array}{r}- \\
8 \\
26\end{array}$ \\
\hline 5 & A.TL-B ${ }^{c}$ & k & $\begin{array}{l}\text { None } \\
\text { Anti-las } \\
\text { Anti-Iak }\end{array}$ & $\begin{aligned} 12239 & \pm 597 \\
14059 & \pm 1043 \\
7969 & \pm 950\end{aligned}$ & $\begin{array}{r}- \\
-15 \\
35\end{array}$ \\
\hline & & & \multicolumn{2}{|c|}{$\begin{array}{l}\text { Mean suppression } \\
\text { Control } \\
P\end{array}$} & $\begin{aligned} 35.6 & \pm 11.8 \\
0.4 & \pm 16.1 \\
& <0.005\end{aligned}$ \\
\hline
\end{tabular}

${ }^{a}$ Expressed as counts per minute ${ }^{3} \mathrm{H}$-thymidine incorporation for quadruplicate cultures.

${ }^{b}$ Cultures were stimulated with $50 \mu \mathrm{g} / \mathrm{ml}$ LPS.

${ }^{C} \mathrm{~A} . \mathrm{TL}-\mathrm{B}=$ splenic $\mathrm{B}$ cells prepared by anti-Thy-1.2 serum and complement treatment of whole spleen.

the spleen cells were incubated with antisera for $3 \mathrm{hr}$, then washed, and cultured with LPS without any greater degree of suppression. Incubation with more concentrated serum dilutions of $1: 2$ also failed to increase suppression, and if incubations with sera were prolonged beyond $3 \mathrm{hr}$, nonspecific suppression occurred.

To eliminate the possibility that the persistent decrease in responsiveness was the effect of anti-Ia serum on $T$ cells, the whole spleen cell suspension was treated with antiThy-1.2 serum and rabbit complement. The anti-Thy-1.2 resistent splenic B cells were then incubated with A.TH anti-A.TL $\left(\mathrm{Ia}^{k}\right)$ serum for $30 \mathrm{~min}$, washed, and cultured with LPS (Expt 5, Table 1). The same partial suppression was observed. Therefore, a Thy-1 positive, Ia positive auxillary $T$ cell was not involved in the suppression.

The inhibitory effect observed with anti-Ia serum was not found when cells were pretreated with antisera specific for $\mathrm{H}-2 \mathrm{~K}$ transplantation antigens, nor with anti-Ia serum pretreatment of an irrelevant target cell. This indicates that there is no association between the $\mathrm{H}-2 \mathrm{~K}$ determinants on the cell membrane and the receptors(s) for LPS. It also demonstrates that simply attaching an antibody to the cell surface will not interfere with the mitogen proliferative response.

Nonspecific inhibition of in vitro responses by even low concentrations of whole mouse serum in the culture media makes it virtually impossible to have the desired antibodies present throughout the culture period. In order to eliminate this problem, the IgG fraction of A.TH anti-A.TL $\left(\alpha \mathrm{Ia}^{k}\right)$ serum was isolated by agarose block electrophoresis. This diluted antiserum retained a cytotoxic titer of $1: 256$ and could be present throughout the culture period without caus- 
TABLE 2

Inhibition of the LPS Mitogenic Response when the IgG Fraction of A.TH Anti-A.TL Serum Was Added to Cultures

\begin{tabular}{|c|c|c|c|c|c|}
\hline \multirow[b]{2}{*}{ Expt } & \multirow[b]{2}{*}{ Strain } & \multirow{2}{*}{$\stackrel{\text { I }}{\text { region }}$} & \multicolumn{2}{|c|}{$\mathrm{cpm} \pm \mathrm{SD}^{a}$} & \multirow{2}{*}{$\begin{array}{c}\% \\
\text { Suppression }\end{array}$} \\
\hline & & & Media & $\overline{\text { Anti-Ia }(\operatorname{IgG})^{b}}$ & \\
\hline \multirow[t]{2}{*}{1} & B10.BR & k & $9438 \pm 2650^{c}$ & $6973 \pm 1862$ & 26 \\
\hline & B10.S & $\mathbf{s}$ & $9552 \pm 1578$ & $8529 \pm 780$ & 11 \\
\hline \multirow[t]{2}{*}{2} & B10.BR & $\mathrm{k}$ & $8209 \pm 506$ & $6181 \pm 750$ & 25 \\
\hline & B10.S & $\mathrm{s}$ & $5093 \pm 1536$ & $5414 \pm 670$ & -6 \\
\hline \multirow[t]{2}{*}{3} & A.TL & $\mathrm{k}$ & $3316 \pm 664$ & $1944 \pm 346$ & 41 \\
\hline & B10.S & $\mathbf{s}$ & $4236 \pm 1416$ & $4443 \pm 675$ & -5 \\
\hline \multirow[t]{2}{*}{4} & B10.BR & k & $2246 \pm 538$ & $1738 \pm 208$ & 23 \\
\hline & B10.S & $\mathrm{s}$ & $2817 \pm 348$ & $3272 \pm 340$ & -16 \\
\hline \multirow[t]{2}{*}{5} & B10.BR & $\mathrm{k}$ & $1742 \pm 611$ & $995 \pm 345$ & 43 \\
\hline & B10.S & $\mathrm{s}$ & $3795 \pm 337$ & $2842 \pm 294$ & 25 \\
\hline \multirow[t]{5}{*}{6} & B10.BR & $\mathrm{k}$ & $2626 \pm 889$ & $1393 \pm 358$ & 53 \\
\hline & B10.S & $\mathrm{s}$ & $4163 \pm 868$ & $3732 \pm 1234$ & 10 \\
\hline & & & \multicolumn{2}{|c|}{ Mean suppression } & $35.2 \pm 12.2$ \\
\hline & & & \multicolumn{2}{|l|}{ Control } & $3.2 \pm 14.9$ \\
\hline & & & \multicolumn{2}{|l|}{$\boldsymbol{P}$} & $<0.005$ \\
\hline
\end{tabular}

${ }^{a}$ Expressed as counts per minute ${ }^{3} \mathrm{H}$-thymidine incorporation for quadruplicate cultures. There was no mitogen effect of anti- $\mathrm{Ia}^{k}(\mathrm{IgG})$ when it was added to spleen cell cultures.

${ }^{b}$ Pool of inhibitory $\gamma$-fractions from agarose block electrophoesis.

${ }^{c}$ Cultures were stimulated with $50 \mu \mathrm{g} / \mathrm{ml}$ LPS. Responses were $2.7-5.0 \times$ control with no LPS.

ing nonspecific suppression or mitogenic response. The results of six experiments are summarized in Table 2 . The mean suppression was $35.2 \% \pm 12.2(P<0.005)$ which was no greater than the suppression observed when cells were incubated briefly with anti-Ia antibodies before culturing with LPS. This consistent partial suppression of the LPS response suggests an association between the LPS receptor and the Ia molecule(s).

Anti-Ia serum blocking of Con-A and PHA stimulation. In order to test for a similar inhibition of $\mathrm{T}$-cell mitogen stimulation, spleen cells were incubated for $30 \mathrm{~min}$ with normal serum, anti-H-2K serum or antiIa serum without complement, washed by centrifugation, and cultured for $72 \mathrm{hr}$ with mitogen. The anti-Ia serum was A.TH antiA.TL $\left(\alpha \mathrm{Ia}^{k}\right)$ serum which is known to have anti-T-cell cytotoxic activity. In four experiments, there was no difference in the Con-A or PHA response of serum pretreated cells when compared to cells exposed only to culture media. Three additional experiments were performed using the T-cell mitogen leucoagglutinin again without any effect on the response. These experiments were always performed over the complete dose range of each mitogen to rule out a change in response kinetics in anti-Ia serum blocked cells.

$L P S$ response of splenic $B$ cells resistant to anti-Ia serum and complement. B10.BR $(H$ $2^{k}$ ) spleen cells were incubated with normal A.TH serum or A.TH anti-A.TL serum (anti- $\mathrm{I}^{k}$ ) diluted 1:2 followed by an incubation with rabbit complement. The cells were centrifuged through a Ficoll-Hypaque gradient, adjusted to equal numbers of viable cells, and cultured with a dose range of LPS. The spleen cells resistant to anti-Ia antibodies and complement did not respond to LPS.

To eliminate the possible involvement of $T$ cells, spleen cells were first treated with antiThy-1.2 serum and rabbit complement. After washing the cells by centrifugation in media, the anti-Thy- 1.2 serum and complement incubation was repeated. The cells resistant to 
anti-Thy- 1.2 serum are greater than $95 \%$ B cells as determined by surface markers and functional assays. The splenic B cells were then treated with normal serum and rabbit complement or A.TH anti-A.TL $\left(\mathrm{Ia}^{k}\right)$ serum and complement. The remaining viable cells after anti-Ia ${ }^{k}$ serum treatment constituted approximately $8 \%$ of the original spleen cell population and equal numbers of these cells were cultured with $50 \mu \mathrm{g} / \mathrm{ml}$ LPS. The B cells resistant to complement dependent anti-Ia serum lysis did not respond to LPS (Fig. 1), indicating that the LPS reactive spleen cells are Ia positive B cells.

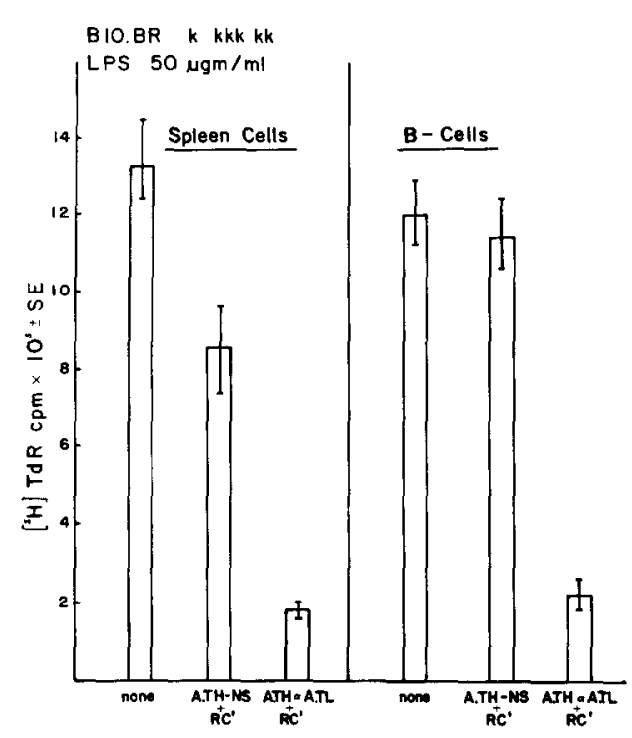

FIG. 1. Proliferative response of B10.BR $\left(H-2^{k}\right)$ spleen cells and splenic B cells to $50 \mu \mathrm{g} / \mathrm{ml}$ LPS. Spleen cells or anti-Thy-1.2 serum and complement resistant $B$ cells were treated either with A.TH normal serum and rabbit complement or with A.TH anti-A.TL $\left(\alpha \mathrm{Ia}^{k}\right)$ serum and complement. Equal numbers of surviving viable cells $\left(5 \times 10^{5}\right)$ were cultured for $48 \mathrm{hr}$ with LPS. Each bar represents the mean of four cultures \pm SE.

The differential expression of the Ia marker on PHA and Con- $A$ reactive $T$ cells. Spleen cells from B10.S $\left(H-2^{s}\right)$ mice were subjected to lysis by A.TL anti-A.TH (anti$\left.\mathrm{Ia}^{s}\right)$ serum and rabbit complement, killing $50-60 \%$ of the lymphocytes. Equal numbers of viable $\mathrm{Ia}^{s}$ negative cells were cultured with Con-A or leucoagglutinin. These cells

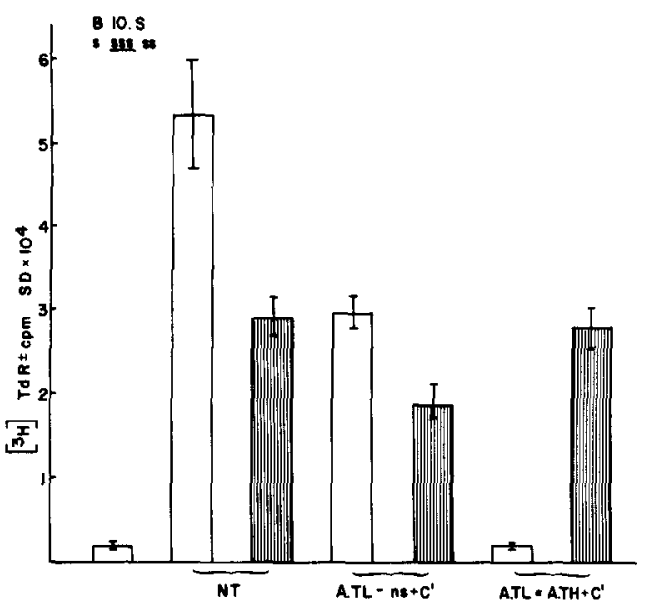

FIG. 2. Con-A and leucoagglutinin proliferative response of A.TL anti A.TH $\left(\alpha \mathrm{Ia}^{s}\right)$ serum and rabbit complement treated B10.S $\left(H-2^{s}\right)$ spleen cells. NT is the response obtained when cells were exposed only to culture media. A.TL-ns $+\mathrm{C}^{\prime}$ represents the response of cells treated with normal serum and rabbit complement. Equal numbers of remaining viable cells $\left(5 \times 10^{5}\right)$ were cultured for $72 \mathrm{hr}$ with either Con-A, $1 \mu \mathrm{g} / \mathrm{ml}$ (open bars) or leucoagglutinin, $1 \mu \mathrm{g} / \mathrm{ml}$ (shaded bars). Each bar represents the mean response of four cultures expressed as $\mathrm{cpm} \pm \mathrm{SD}$. The open bar at the left of the graph is the background response in unstimulated cultures.

responded normally to leucoagglutinin but did not respond to Con-A (Fig. 2). Four experiments were performed including two with B10.BR $\left(H-2^{k}\right)$ spleen cells and A.TH antiA.TL $\left(I^{k}\right)$ serum with identical results.

The experiments were repeated using splenic $T$ cells isolated by incubating the spleen cell mixture on nylon-wool columns. The first cells washed off the column by the addition of $15 \mathrm{ml}$ culture media were greater than $90 \%$ Thy-1.2 positive $T$ cells. The nylon-wool $T$ cells were incubated with antiIa serum and complement. Equal numbers of surviving $T$ cells were cultured with Con-A, PHA, or leucoagglutinin. These cells failed to respond to Con-A (Fig. 3). Although not shown in Fig. 3, these cells gave a normal response to PHA and leucoagglutinin.

The Con-A sensitive lymphocyte, therefore, is a Thy-1 positive, Ia positive $T$ cell distinct from the PHA or leucoagglutinin reactive Thy-1 positive, Ia negative $T$ cell. 


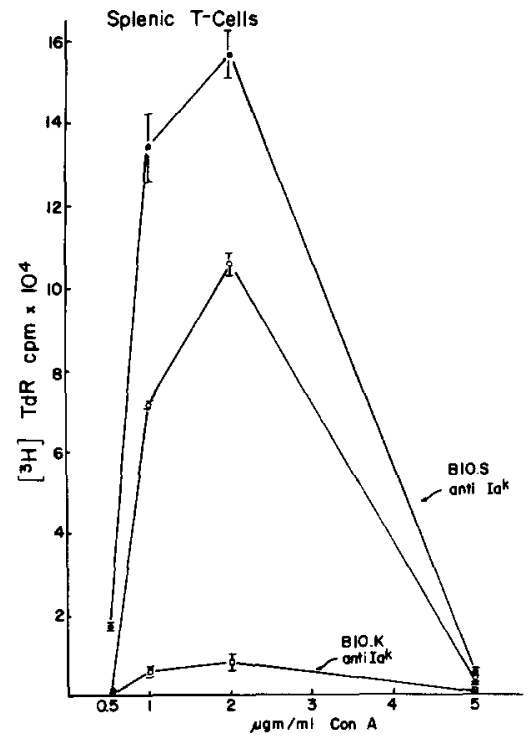

FIG. 3. Con-A proliferative response of nylon-wool purified splenic T-cells resistant to treatment with A.TH anti A.TL $\left(\alpha \mathrm{Ia}^{k}\right)$ serum and rabbit complement. Equal numbers of surviving viable cells $\left(5 \times 10^{5}\right)$ were cultured for $72 \mathrm{hr}$ with mitogen. (०--) Nontreated splenic $\mathrm{T}$ cells from B10.K $\left(H-2^{k}\right)$ mice; $(\bullet-)$ anti-Ia ${ }^{k}$ serum plus complement treated B10.S $\left(H-2^{5}\right)$ cells; and ( $\left.\square-\right)$ anti-Iak serum plus complement treated B10.K cells. Each point represents the mean response of four cultures expressed as counts per minute \pm SD.

\section{DISCUSSION}

These experiments have defined a subpopulation of Con-A reactive $T$ lymphocytes which is Ia and Thy-1 positive and distinct from the subset of T cells which is PHA or leucoagglutinin reactive. The latter subpopulation is Thy-1 positive but is not susceptible to lysis by anti-Ia serum and complement. The demonstration of a functional class of Ia reactive $T$ cells supports the findings of our previous cytotoxic and absorption studies indicating the existence of an Ia positive $T$ cell population [10]. Demonstration of Ia positive thymocytes by other investigators using the fluorescence-activated cell sorter [18] and of Ia sensitive Con-A activated thymocyte and splenic blasts $[16,17]$ give additional support to these observations.

The fact that distinct subsets of $T$ lymphocytes are specific for Con-A and PHA mitogens and that they also have differing Ia expression is consistent with a number of recent findings. For example, Cantor and Boyse [18, 19] and Kisielow et al. [20] have demonstrated that "helper" $\mathrm{T}$ cells are distinct from "killer" $T$ cells and that "helper" cells express the Ly-1 antigen while "killer" cells express Ly-2,3. Graft-vs-host cells comprise yet another subpopulation and express $L y-1$ and $L y-2$ antigens.

Cytotoxic and absorption studies have indicated that the Ia antigens are expressed on the membranes of most B lymphoid cells and macrophages. It was, therefore, not surprising that the removal of the majority of the splenic B cells by anti-Ia serum and complement eliminated the response to LPS. More significant were the experiments designed to test if the simple binding of specific anti-Ia antibodies to the cell membrane would interfere with mitogen stimulation. These experiments were important for two reasons. First, it was recently shown that LPS is a potent polyclonal B cell activator nonspecifically inducing immunocompetent $B$ cells to proliferate and/or secrete antibody [21, 22]. This cell triggering occurs without the involvement of the variable part of the $\mathrm{Ig}$ receptor and is not dependent upon accessory cells (for review, Ref. [23]). Second, we observed that covering of the Ia surface molecule(s) of spleen cells with specific antiIa antibodies inhibited the in vitro primary and secondary humoral response to heterologous erythrocytes [24]. This blocking of the humoral response was specific for anti-Ia serum with no inhibition occurring with anti$\mathrm{H}-2 \mathrm{~K}$ serum. These experiments implicate the involvement of the Ia determinant in cell triggering and/or cell collaboration in the immune response. The finding, therefore, that simple pretreatment of splenic B cells with anti-Ia serum without complement also suppressed the LPS proliferative response suggests the involvement of the Ia molecule in the events of $B$ cell triggering. The fact that this suppression was only partial $(\sim 30 \%)$ necessitated the performance of a number of experiments to insure that this was a consistent observation.

It is unlikely that the observed blocking 
was mediated by the Fc portion of the anti-Ia antibody molecule since antibodies specific for $\mathrm{H}-2 \mathrm{~K}$ and $\mathrm{H}-2 \mathrm{D}$ determinants had no detectable effect. For the observed blocking with anti-Ia whole serum or with the IgG fraction of anti-Ia serum to occur via the Fc portion of the antibody, one must assume that the anti-Ia heavy chains have a unique constant region. This would be highly unlikely.

The inhibition was clearly a B cell specific event since it was not affected by elimination of splenic $T$ cells. The most obvious interpretation is that the Ia molecule(s) and LPS receptors(s) are either the same molecule, or they are in the same supramolecular complex on the cell membrane. The fact that inhibition was only partial suggests, rather, that if LPS triggering is a simple switch event, then some cells have Ia and LPS receptors in close association on their membranes and are inhibited while other cells have non-Ia associated LPS receptors and are triggered. This could also imply the existence of at least two classes of LPS receptor molecules.

Andersson et al. [25] have observed that antibodies directed against the Ig receptors on B cells had no effect on the LPS proliferative response but did inhibit the LPS induction of polyclonal IgM synthesis. Furthermore, "capping" of surface Ig on B cells did not interfere with their proliferative response to LPS [26]. Therefore, it also will be important to test the ability of anti-la serum to inhibit polyclonal responses to LPS and other B cell mitogens.

The failure to block Con-A stimulation by the pretreatment of spleen cells with anti-Ia serum may simply reflect the fact that the receptors for this mitogen are quite distinct from surface Ia determinants. The absence of mannose, the membrane binding sugar for Con-A, in the Ia antigen structure also may be significant.

There is no question that the Ia molecules are distinct from classical transplantation antigens. They are found on molecules with a molecular weight of 25,000 to 33,000 daltons
[11], are glycoproteins [27], and cap independently of the H-2K and H-2D transplantation antigens [28]. Recently it has been shown that anti-Ia sera react directly with both cell-bound and soluble molecules involved in a number of immune phenomena [29]. This surface marker and the antisera directed against the multiple specificities of this region, therefore, will be important tools in the further study of the events of antigen recognition, cell triggering, and cellular interaction in the immune response.

\section{SUMMARY}

Genes located in the $I$ region of the $\mathrm{H}-2$ complex control a system of lymphocyte alloantigens (Ia) which are expressed on subpopulations of $T$ and $B$ cells. Specific anti-Ia serum plus rabbit complement removed the B-lymphocyte population responsive to the mitogen LPS and the subpopulation of T cells responsive to Con-A. Lymphocytes sensitive to PHA or leucoagglutinin were not removed by anti-Ia serum and complement. Significant inhibition of the proliferative response to LPS was also obtained by brief periods of cell pretreatment with anti-Ia antibodies without complement. This inhibition was specific with the appropriate anti-Ia serum and did not occur with anti-H-2K sera or when cells of a different $I$ region were pretreated.

\section{ACKNOWLEDGMENTS}

We thank Patricia Shoffner, Laura Mayo, Carolyn Rosio, and Deirdre Smith for their excellent technical assistance and Nancy Cuthbert for secretarial assistance.

\section{REFERENCES}

1. David, C. S., Stimpfling, J. H., and Shreffler, D. C. Identification of specificity $\mathrm{H}-2.7$ as an erythrocyte antigen: control by an independent locus, $H-2 G$, between the $S$ and $D$ regions. Immunngenetics 2:131, 1975 .

2. McDevitt, H. O., Deak, B. D., Shreffler, D. C., Klein, J., Stimpfling, J. H., and Snell, G. D. Genetic control of the immune response. Mapping of the Ir-1 locus. J. Exp. Med. 135:1259, 1972.

3. Shreffler, D. C., David, C. S., Gotze, D., Klein, J., McDevitt, H., and Sachs, D. Genetic nomenclature 
for new lymphocyte antigens controlled by the $I$ region of the H-2 complex. Immunogenetics 1:189, 1974.

4. Shreffler, D. C., and David, C. S. The H-2 major histocompatibility complex and the $I$ immune response region: genetic variation, function, and organization. Advan. Immunol. 20:125, 1975.

5. David, C. S., Shreffler, D. C., and Frelinger, J. A. New lymphocyte antigen system (Ina) controlled by the Ir region of the mouse H-2 complex. Proc. Nat. Acad. Sci. 70:2509, 1973.

6. Hauptfeld, V., and Klein, D. Serological identification of an Ir-region product. Science 181:167, 1973.

7. Sachs, D. H., and Cone, J. L. A mouse "B" cell alloantigen determined by gene(s) linked to the major histocompatibility complex. J. Exp. Med. 138:1289, 1973.

8. Hammerling, G. J., Deak, B. D., Mauvc, G., Hammerling, U., and McDevitt, H. O. "B" lymphocyte alloantigens controlled by the $I$ region of the major histocompatibility complex in mice. Immunogenetics $1: 68,1974$.

9. Gotze, D., Reisfeld, R. A., and Klein, J. Serologic evidence for antigens controlled by the $I r$ region in mice. J. Exp. Med. 138:1003, 1973.

10. Frelinger, J. A., Niederhuber, J. E., David, C. S., and Shreffier, D. C. Evidence for the expression of Ia (H-2I associated) antigens on thymus derived lymphocytes. J. Exp. Med. 140:1273, 1974.

11. Cullen, S. E., David, C. S., Shreffler, D. C., and Nathenson, S. G. Membrane molecules determined by the $\mathrm{H}-2$ associated immune response region: isolation and some properties. Proc. Nat. Acad. Sci. 71:648, 1974.

12. Muller-Eberhard, H. J. A new supporting medium for preparative electrophoresis. Scand. J. Clin. and Lab. Invest. 12:33, 1960.

13. Nowotny, A., Cundy, K. R., Neale, N. L., Nowotny, A. M., Radvany, R., Thomas, S. P., and Tripodi, D. J. Relation of structure to function in bacterial $\mathrm{O}$ antigens. IV. Fractionation of the components. $A n n$. New York Acad. Sci. 133:586, 1966.

14. Julius, M. H., Simpson, E., and Herzenberg, L. A. A rapid method for the isolation of functional thymus derived murine lymphocytes. Eur. J. Immunol. 3:645, 1973 .

15. Fathman, C. G., Cone, J. L., Sharrow, S. O., Tyrer, H., and Sachs, D. H. Ia alloantigen(s) detected on thymocytes by use of a fluorescence-activated cell sorter. J. Immunol. 115:584, 1975.

16. David, C., Meo, T., McCormick, J., and Shreffler, D. Expression of individual la specificities on $T$ and B cells. I. Studies with mitogen induced blast cells. J. Exp. Med: 143:218, 1975.

17. Hauptfeld, M., Hauptfeld, V., and Klein, J. Ia and
H-2 antigens on blast cells. Transplantation 19:528, 1975.

18. Cantor, H., and Boyse, E. A. Functional subclasses of $\mathrm{T}$ lymphocytes bearing different Ly antigens. I. The generation of functionally distinct $\mathrm{T}$-cell subclasses is a differentiation process independent of antigen. J. Exp. Med. 141:1376, 1975.

19. Cantor, H., and Boyse, E. A. Functional subclasses of $\mathrm{T}$ lymphocytes bearing different Ly antigens. II. Cooperation between subclasses of Ly + cells in the generation of killer activity. J. Exp. Med. 141:1390, 1975.

20. Kiseelow, P., Hirst, J., Shiku, H., Beverly, P. C. L., Hoffman, M. K., Boyse, E. A., and Oettgen, H. F. Ly antigens: markers for functionally distinct subsets of thymus-derived lymphocytes of the mouse. Nature (London) 253:219, 1975 .

21. Coutinho, A., and Möller, G. Immune activation of B cells. Evidence for one nonspeciflc triggering signal not delivered by the $\mathrm{Ig}$ receptors. Scand. $J$. Immunol. 3:133, 1974.

22. Melchers, F., and Andersson, J. Changes in synthesis, turn-over and secretion, and in numbers of molecules on the surface of B cells after mitogenic stimulation. Eur. J. Immunol. 4:181, 1974.

23. Gronowicz, E., and Coutinho, A. Functional analysis of B cell heterogeneity. Transplant. Rev. 24:3, 1975.

24. Frelinger, J. A., Niederhuber, J. E., and Shreffler, D. C. Inhibition of immune responses in vitro by specific antiserums to Ia antigens. Science 188:268, 1975.

25. Andersson, J., Bullock, W. W., and Melchers, F. Inhibition of mitogenic stimulation of mouse lymphocytes by anti-mouse immunoglobulin antibodies. I. Mode of action. Eur. J. Immunol. 4:715, 1974.

26. Elson, C. J., Singh, J., and Taylor, R. B. The effect of capping by anti-immunoglobulin antibody on the expression of cell surface immunoglobulin and on lymphocyte activation. Scand. J. Immunol. 2:143, 1973.

27. Cullen, S. E., Freed, J. H., Atkinson, P. H., and Nathenson, S. G. Evidence that protein determines Ia antigenic specificity. Transplant. Proc. 8:237, 1975.

28. Unanue, E. R., Dorf, M., David, C. S., and Benacerraf, $B$. The presence of I-region-associated antigens on B cells in molecules distinct from immunoglobulin and H-2K and H-2D. Proc. Nat. Acad. Sci. $71: 5014,1974$

29. David, C. S., Niederhuber, J. E., Frelinger, J. A., Dugan, E. P., Meo, T., and Shreffler, D. C. Murine Ia antigens. Expression on $T$ and $B$ cells and their role in immune response. In Proceedings of the 10th Leucocyte Culture Conference. Academic Press New York, in press. 